\title{
Leading Learning and Teaching in Higher Education -Enhancing Academic Practice and Innovations
}

\author{
Dr. Vinod Kumar
}

Assistant Professor (English), Amity School of Liberal Arts, Amity University Haryana, India

\begin{abstract}
Teaching -Learning is coming out as an important area on this planet pertaining to higher education on account of changing nature of students, improvement of modern information communications tools and certain demands from higher education inclined to placement and other job opportunities or entrepreneurship so the teaching -learning process can be categorized in different ways, some are more peculiar to general way while other wanted to analyze the intricacies and complexities in higher education. The paper goes through some prominent theories pertaining to teaching-learning in higher education. This paper will let you know about the various levels of teaching, efficiency, capabilities, presence of mind, concentration and certain outcomes and possibilities on learning. It has also been observed that there are certain factors which create a kind of impact in higher education throughout the world. For this we have to include external factors excluding teachers, students and pedagogy. This paper emphasizes that there is an urgent need to search or develop tool with introspection to meet this challenge of teaching -learning process in higher education beyond theoretical model but with an aim to facilitate, analyzing and deciphering teaching-learning from different perspective and dimensions.
\end{abstract}

Keywords-Higher Education, Innovative tools, Teaching skills.

\section{INTRODUCTION}

The role of the academicians and scholars in higher education pertaining to reform and expansion under the scanner and quality of teaching has been found prominent factor of contemporary discourse. Academician's honesty has been called in question on account of their inaccessibility general public, society and entrepreneurs market. It is surprising that in spite of never ending research pertaining to teaching -learning at every level, still the on-going research approaches don't stand with the appetite of students. No doubt, pedagogy or teaching is anchor sheet activity in the temple of knowledge for every standard but the improvement is the wide of the mark. However, the steps towards improvement in teaching especially in colleges and universities have been taken very late and didn't come to expectations.

The paper will also tell us about the teaching in the contemporary higher education doesn't come up to that standard the learners are always on the margin of suffering and approach from the on-going conventional mode of teaching. So, the need of the hour is to take concrete steps in this regard as it has been ascertained beyond doubt that teaching is governed by market forces nowadays and must adopt pragmatic and empirical approach by the academicians. The paper states that the teaching -learning analysis must be context specific situated in time and space.

D' Rozario (2020) argues that today, it is difficult to give an accurate number of languages available across the world because a particular language has many sub-plots as per its dialects. Further Mishra (2020) agrees that the linguistic variety, diversity and multi-linguistic approaches are dominant over the entire world and India in not an exception. So the main motto of this paper is to understand teaching and learning from various points of view. Besides that, it is an attempt to know the theoretical way blended with teaching learning, their progress, advancement and development and to design a mode by associating the theoretical approaches and result oriented factors of teaching- learning which help to assess the issues in every ways and holistically. 


\section{The Changing Discourse of Learning}

Today, the job title form any leaders has merely become a source of money. After getting your desired job title, most of them lose their passion. Then, People lose their love for their jobs and "work" becomes a noun rather than a verb which result in very low engagement in work or business and after seeing these leaders, employees also lose their motivation. We cannot always depend on the leaders above us. Therefore, we have to start leading ourselves (Manshi, 2019). The global trends in the education advocates that man focus towards learning rather than education because learning means to engage in all kinds of learning activities adopted by learner whereas education is confined up to formal and structured system. So in learning the focus is on the learner because it is more individual in nature, personalized in form. No doubt, it is learner oriented and interactive. On the contrary teaching comes outwardly, so the priority is given to teaching. Mishra (2019) asserts that a framework of immediate response might be considered of great importance, where the teacher shall be able to suggest to the learners an effective methods to resolve the problems with regard to the comprehension or use of language form. In this category, the observation may rely on the following indicators for effective teaching performance: stimulating amenable and productive strategies; reflection on use of strategy; drawing a framework to synthesize the output oriented strategies. These five assumptions can be considered as the basic ingredients for effective language learning and teaching activities. Moreover, learning is a fine blend of formal, non-formal and informal ways of learning to get knowledge, skills and efficiency by inclusion of interaction actively with the persons of all age group by considering every type of aspects socially, economically, vocationally and liberally. There are many factors which create many impacts on the role of learning. The new technologies have also brought many changes. Some are as under:

- In the most advanced and developed countries are losing their control on the transmission of information because the media, the internet and other commercial software re are offering accessibility to have information. So the worldwide revolution owing to technology has created the option for online teaching having the potentiality to replace the physical presence of a teacher. The repercussion is that many universities and other higher educational institutions are providing diplomas and degrees to the students. These perceptible changes confirm that learners are now responsible for their own learning.
- Now in these circumstances education is no longer the responsibility of the states because of the paradigm shift from state to market. For this, the driving force is the flexibility and multidimensionality.

- It has also been observed that in some cases learning has become a tool for personal satisfaction because it provides opportunity for an individual to update and upgrade himself to remain stable and to stay competitive.

\section{The Changing Discourse of Teaching-Learning in Higher Education}

It is a well- known fact that to acquire higher degrees or in a pursuit of high degrees the students have to invest a lot. Sometimes higher degrees become white elephant. So the monetary outlook and utilitarian attitude and other market forces have increased the external demands for quality teaching globally. To deal with the student's expectations and responsibilities of the clients, it is very difficult to define what is good or quality teaching. But with the changing educational landscape and on the basis of the market approach we can define as "Value for Money".

\section{THEORIES OF TEACHING- LEARNING}

The term teaching can be used in a broad ways consisting of managerial and organizational aspects of learning. But teaching has certain generic features:

- The first idea of effective teaching encompasses sets of teaching skills as a profession is complex. Teaching effectiveness is directly proportional to the scores achieved by the students. Teacher's ability to respond innovatively and reflect upon practices is highly valued.

- The critiques consider teaching behavior as a process and student achievement as product. So the basic premises considered that an effective teacher's behavior would result in the growth of student knowledge and skills. But the scholars and researchers set new guidelines and laid stress on direct instructions as a mechanism to give great knowledge gain to the students. So this learning and cognitive achievement on account of stepwise guidelines and instructions became the sine qua non for the mantra of effective teaching.

\section{Teaching as Skills}

Kyriacou (1991) gave three important points: 
- $\quad$ Subject knowledge of the teacher, curriculum and teaching methods have influence on teaching and learning can create an impact for his own teaching

- Action and overt behavior to foster and promote effective learning by the teacher

- Decision making, thinking and reflecting before, during and after a classroom lesson can have a cumulative impact on effective teaching and teaching development

\section{Styles of Teaching}

How to teach effectively? This question probably has got maximum importance in literature. But one of the relevant task done by Joyce and Weil (1996) advocates that - There are four main families or the model of teaching based on learning and orientation of how people learn.

- Information Processing Family Model: To organize data, sensing concepts, and produce solutions to the problems. This will help the learner to construct the knowledge.

- Social Family Mode: This model supports the cooperative learning approaches, higher order thinking, social skills and team work and so on. This model helps the student to sharpen the cognition through the group and interpersonal interaction.

- The Personal Family Model: It focuses on the individual. It helps to design education so that the individual can explore and understand better.

- The Behavioural System Family: It emphasizes on the stimulus and response.

\section{Using MATT (Multi-Dimensional Analytical Tool for Teaching Learning)}

This tool helps to analyze some major components and their inter-linkages. So there are two areas to explain Components and inter-linkage in studies. This section initiates the discussion with the components and these are:

- Students or Learners

- Teachers

- Institutional or Administrative

\section{CONCLUSION}

This paper has taken clues from theoretical discourses and used them in a developing MATT. It is multi-dimensional and will help to examine. Teaching-Learning from different perspective and aspects. This paper, in spite of its limitations will try to give a concrete solution for the research scholars and will be helping side to understand the core issue pertaining to Teaching-Learning from different dimensions and levels. If we look back at the conventional model of education, we find that the success of those students totally depends on, what we don't see are the countless hours they consumed behind the divisions, improving their expertise, and edifying their skills. Today's Indian workforce is massively talented and adaptable. It focuses not only on economic, infrastructure and technical development but also tend to lead the nation towards industrial development, giving a global recognition in Indian Industry (Mishra, 2020). The research progress using above mentioned tools will come out with microcontext factors and components which further would be more beneficial to the generation to come regarding the knowledge.

\section{REFERENCES}

[1] Barr, R. and Tagg J. (1995) From Teaching to Learning: A New Paradigm for Undergraduate Education

[2] Bauman, Z. (2005) Liquid Life. Malden: Polity Press

[3] Bennett, N. (1988) The Effective Primary School Teacher: The Search for a Theory of Pedagogy

[4] Burner, J.s. (1960) The Process of Education. Cambridge: Harvard University Press.

[5] Biggs, J. P. Moore (1993) The Process of Learning. New York: Prentice Hall

[6] Chung, C (2011): New Horizon in Education

[7] Clark, C. M. \& Peterson, P. L. (1986) Teachers Thought Process. New York: Macmillan, pp. 255-296

[8] D' Rozario, P. \& Mishra, S. K. (2020). Contemporary Tibetan Literature in English: Witnessing Exile. International Journal of English Literature and Social Sciences. 5(2), pp. 441-445. https://ijels.com/detail/contemporary-tibetan-literature-inenglish-witnessing-exile/ http://doi.org/10.22161/ijels.52.18

[9] Field, J. (2006) Lifelong Learning and the New Educational Order. Sterling: Trentham Books

[10] Galton, M, B. Simon and P. Croll (1980) Inside the Primary Classroom. London: Routledge and Kegan Paul

[11] Good, T.L. and J. Brophy (1980) Educational Psychology: A Realistic Approach (2 $2^{\text {nd }}$ ed) New York: Holt, Rinehart and Winston

[12] Goodwin, A. L. (2010) Globalization and the Preparation of Quality Teachers: Rethinking Knowledge Domains for Teaching, Journal of Teacher Education

[13] Harvey, L. and D. Green (1993) Defining Quality, Assessment and Evaluation in Higher Education

[14] Henard, F. and S. Leprince- Ringuet (2008) The Path to Quality Teaching in Higher Education

[15] Jayaram, N. (2002) The fall of Guru: The Decline of Academic Profession in India.

[16] Jarvis, P. (2008) Democracy, Lifelong Learning, and Learning Society. New York: Routledge 
[17] Joyce, B. and M. Well (1996) Models of Teaching, Boston : Allyn and Bacon

[18] Kyriacou, C. (1991) Essential of Teaching Skills. Oxford: Basil Blackwell.

[19] Mandal, S. (2016) Teaching- Learning Process, Economic and Political Weekly, 51(29), pp. 273-279.

[20] Manshi, \& Mishra, S. K, (2019). Self-Leadership as a Tool for Enhancing Performance at Workplace. GIS Business. 14 (6). pp. 76-88 https://journals.eduindex.org/index.php/gis/article/view/1162 8 http://doi.org/10.5281/zenodo.3782700

[21] Mishra, S. K, \& Mishra, P. (2019). Content and Language Integrated Learning: A Paradigm Shift in ELT. International Journal of Innovations in TESOL and Applied Linguistics. 4 (3). http://ijital.org/images/issues/issue-14th/2\%20Sunil.pdf http://doi.org/10.5281/zenodo.3782714

[22] Mishra, S. K. \& Mishra, P. (2020). Functional Aspects of Communication Skills for Professional Empowerment. Journal of English Language and Literature. 7(1). pp. 79-85 http://joell.in/wp-content/uploads/2020/03/79-85-

Communication-Skills-For-Professional-Empowerment.pdf http://doi.org/10.333329/joell.7.1.79

[23] Mishra, S., \& Mishra, P. (2020). Exploring Communicative Skills as Workforce for Dynamic Entrepreneurship. Pedagogical Research, 5(4), em0067. https://www.pedagogicalresearch.com/article/exploringcommunicative-skills-as-workforce-for-dynamicentrepreneurship-8249 https://doi.org/10.29333/pr/8249

[24] Piaget, J. (1950) The Psychology of Intelligence. London; Routledge and Kegan Paul

[25] Rizvi, F. and B. Lingard (2010) Globalizing Education Policy. New York : Routledge

[26] Wragg, E. C. (1984) Classroom Teaching Skills. London: Croom Helm. 